\title{
A bandeira em sua origem vocabular (*)
}

\section{Waldemar Gola}

I. A lição de José Joaquim Nunes e Adolfo Coelho. II. O radical germanico indicado por Carlos Góis. III. A palavra "bandeira" no vocábulo dos clássicos. - IV. Bandeira sim, bandeirante não. - V. Bandeirante, porque? - VI. Bandeirante e bandeirismo na derivação gramatical. - VII. Outras derivações menos empregadas. - VIII. Retorno ao problema etimologico. IX. O que registra o Dicionário Etimológico de Antenor Nascentes. - X. A resposta de Augusto Magne. Conclusão.

“ ainda que a noticia dos vocábulos é de todos, saber a origem dêles e só dos que sabem as coisas e mais as causas".

(Pe. Antonio Vieira, Sermão de Nossa Senhora do Rosário, XXVII, 2a parte).

\section{A lição de José Joaquim Nunes e Adolfo Coelho}

A palavra bandeira não se derivou do latim. Nenhum substantivo, ou qualquer outra categoria gramatical, existe, nessa língua, capaz de dar origem ao referido vocábulo.

O substantivo apelativo neutro vexillum, $i$, (de vehere), que o dicionarista Santos Saraiva traduz por bandeira, estandarte, não forneceu a nenhuma língua néo-latina o radical dêsse têrmo.

(*) Dissertação apresentada ao Prof. Dr. Waldemar Ferreira, na cadeira de História do Direito Nacional, do Curso de Doutorado da Faculdade de Direito da Universidade de São Paulo. 
Os filólogos e dicionaristas que consultamos, embora divergindo em outros pontos, são unânimes em silenciar qualquer relação entre essas duas palavras, pois, efetivamente, nenhuma lei fonética existe, capaz de justificar essa transformação.

O Dr. José Joaquim Nunes, no seu Compêndio de Gramática Histórica Portuguesa, refere-se duas vêzes à palavra bandeira, dando-a como derivada de bandaria, expressão que escreve precedida de asterisco $\left({ }^{*}\right)$, para indicar, de acôrdo com a convenção comum às obras de filologia, que se trata de palavra hipotética, "isto é, não existente nos textos, mas deduzida das várias línguas românicas. (1).

A lição de José J. Nunes coincide com a de Adolfo Coelfo, segundo o confirma Antenor Nascentes, no seu Dicionário Etimológico, verbete bandeira.

\section{II - O radical germânico indicado por Carlos Góis}

No seu precioso Dicionário de Raizes e Cognatos da Lingua Portuguesa, Carlos Góis indica a raiz germânica band, com o significado de ligar, reunir, como sendo o embrião das palavras band (o) e band (eira), afirmando

(1) Compêndio de Gram. Hist. Port. - 3.a ed. - 1945, introd. pág. XII. As referências à palavra bandaria estão nas páginas 179 e 191. A respeito dêsses vocábulos tidos como existentes em determinada fase de uma língua, mas de que não há provas escritas, vem a proposito citar o seguinte passo de MANiuEl de PAIVA BOLÉo, extraido seu livro Introdução ao Eatudo da Filologia Portuguesa (edição da Revista de Portugal, Lisboa, 1946, pág. 25) : "O grande fundo do nosso léxico é, como se sabe, de proveniência latina, do sermo rusticus falado nésta província romana que se chamou Lusitânia, de que fazia parte o território portucalense. Muitos vocábulos não foram fixados em textos literários, mas isso não nos impede de admitir; com relativa segurança, a sua existência. Há, portanto, formas reconstituidas ou intermédias que é perfeitamente legitimo pressupôr; o que se torna necessário é proceder com a devida cautela." 
que, désta última, é que "no Brasil se formou band-eir (a)ante".

Se bem apreendemos sua lição, quiz Carlos Góis, dizer que a palavra bandeirante formou-se no Brasil, embora o vocábulo bandeira tenha vindo de Portugal.

\section{A palavra bandeira no vocabulário dos clássicos}

Realmente, bandeirante não, mas bandeira é palavra encontradiça nos clássicos da éra dos descobrimentos.

Afrânio Peixoto e Pedro A. Pinto, no Dicionário d' Os Lusíadas, assinalam sua presença em quatorze versos do poema, e se bem verificamos, significando sempre estandarte, pavilhão, lábaro ou pendão.

Com o mesmo sentido encontramos a palavra empregada por GIL VicENTE, que, na Exortação da Guerra, a põe nos lábios de Policena, nos seguintes versos:

Senhores guerreiros, guerreiros, e vós, senhoras guerreiras, bandeiras e não gorgueiras lavrai pera os cavaleiros. (2).

Curioso é assinalar que na mesma época, no tão dilatado número de páginas de "As Peregrinações" não usou Fernão Mendes Pinto, nem uma só vêz, a palavra bandeira. Empregou estendarte (por estandarte), numerosas vêzes, conforme se vê no vocabulário que encerra o volume VII da edição organizada por A. J. DA Costa Pimpão. (3).

Por outro lado, usando a mesma linguagem, pois que lhe foi contemporâneo, Camões quatro vêzes escreveu essa

(2) Na edição crítica do Prof. João de Almeida Lucas, Rev. do Ocidente - Lisboa 1944. No glossário aposto ao fim da obra, o seu autor observa: "bandeiras — s. f. pl. v. 353. Do latim "bandarias" Segue, assim, a lição de J. J. Nunzs.

(3) As Peregrinações de Fernão Mendes Pinto. Portucalense. Editora, Porto, 1945. 
palavra em Os Lusíadas, mas à moderna, como a escrevemos agora, o que verificamos com cuidado, confrontando os vários passos do poema. (4).

Parece não ser êsse o único exemplo onde se nota a preferência do Poeta por formas e expressões mais novas, a exprimir um permanente esforço no sentido da renovação e enriquecimento da língua, o que, aliás, foi notado pelo eminente camonista que sempre se revelou o nosso grande Afrânio Peixcto. Em conferência que integra o livro Arquivo Camoniano, publicado pela Academia Brasileira de Letras, em 1943, lembra Afrânio, apoiado em FARIA E SousA, o uso feito pelo poeta, de cerca de 120 palavras "que entonces se podia llamar peregrinas", assim como de 150 latinismos, êstes contados por Antenor Nascentes, o que bem mostra a modernidade do espirito de Camões, maximé tendo-se em conta que o número de arcaismos por êle aproveitados não passou de quinze...

Assinala-se ainda o emprego da palavra bandeira, feito por Afonso de Albuquerque (Cartas, 169), JoÃo de Barros (Décadas, I, 1,7) e Ferreira de Vasconcelos, (Eufrosina), exemplos êsses enumerados numa edição recentíssima do Dicionário de MoraIs, em seis volumes, feita sob a direção de Augusto Moreno, José Pedro Machado e Cardoso Junior.

Também Fernão Lopes, com o destempero ortográfico da época, assim empregou o têrmo: "E êstes tinham huuma alta bandeira de San Jorge e outros balsoões de mestura; assy que a az da auamguarda com suas allas era semeada de bamdeiras (sic) e pendões como a cada hum prazia de teer. ." (5).

(4) Os Lusíadas em edição fac-similada na de 1572. Editora Revista do Ocidente 1943.

(5) Fontes Medievais da História de Portugal - Seleção, Prefácio e Notas de Alfredo Pimenta - Classicos Sá da Costa, Lisboa 1948, vol. I, pag. 313 . 
Bandeira sim, bandeirante, não.

Ora, se a palavra bandeirante não é empregada pelos escirtores portugueses e brasileiros anteriores ao evento dêsse fenômeno histórico, então assiste razão a CarLos Góis; ela aquí se criou para denominar o tipo social que integrava a bandeira.

E bandeira, nas acepções analógicas, é também palavra cunhada no Brasil? Qual a resposta dos dicionaristas?

Embora sem ter feito sôbre isso uma pesquiza muito longa, parece-nos que se pode dar uma resposta negativa. Morais, no Dicionário da $2 .^{a}$ edição, de 1813 , assinala, abonado em Rui de Pina, uma acepção que já se aproxima do sentido que depois se emprestou à palavra bandeira, significando não sòmente estandarte, mas símbolo de poder e honra: "Deu-lhe acrescentamento de conde e bandeira quadrada".

Assinale-se de passagem, e não sem despropósito com o assunto versado, que na mesma edição do Dicionário de MoraIs, pode-se verificar a diferença que existe entre as palavras bandeira e estandarte, que não são inteiramente sinônimas, pois alí está, extraída do mesmo RUI DE PINA, a seguinte frase: "cortou as pontas do estendarte e ficou em bandeira quadrada como Principe", o que mostra ser o estandarte a insígnia triangular alongada, dos lanceiros e cavalarianos antigos, ao contrário da bandeira, que em forma e hierarquia era cousa diferente.

Vê-se pois, que o emprego da palavra bandeira começou muito cedo a ser feito em sentido analógico, como se verifica também do seguinte exemplo tirado de Ferreira DE VAsconcelos. (Eufrosina, passim), que vem citado na referida edição do Dicionário de Monais e outros: “. se partiu levando em outros capitais de sua bandeira".

Mas no sentido de entrada "e correspondente ao que os espanhois denominavam maloca, o nome de bandeira só 
começou a ser usado no Brasil do século XVII, a centúria das grandes e atrevidas expedições do Brasil a dentro", afirma Bernardno José de Sousa, no seu Onomástico Geral da Geografia Brasileira, seguindo lição de AFonso DE Taunay.

A êsse propósito também discorre Alcântara Machado: "Bandeira e bandeirante são palavras que não aparecem, com o sentido que hoje em dia lhes emprestamos, nos inventários divulgados. Só em $1726 \mathrm{um}$ documento do padre João Gomes, superior da missão jesuítica de Paranaguá, menciona o fato do povoador de Laguna ter despedido uma bandeira com trinta pessôas, cujo cabo é João DE Magalhães, a povoar o Rio Grande.

Nada denuncia também que em São Paulo tenham adquirido fóros de cidade as palavras maloca e maloquero, de cunho nitidamente crioulo, com que os hispano-americano designavam respectivamente a expedição e o expedicionário.

À incursão os documentos paulistas do tempo chamam entrada, jornada, viagem, companhia, descobrimento $\mathrm{e}$, mais raramente, frota.

Para individualizá-la nomeiam o organizador ou cabeça: entrada de Domingos Rodrigues de Paraupava, entrada de Macedo, entrada que fêz Belchion Carneiro, entrada adonde vai LÁZARo DA CosTA, entrada que vai fazer por mandado de Diogo de Quadros, viagem de Diogo Fernandes, viagem que Simão Alvares fêz ao Caeté, jornada, companhia, guerra de Nicolau Barreto. Ou então o lugar do destino: viagem de Itaquí, entrada do rio Guaibihí, viagem aos Amboupuras.

Guerra é o têrmo empregado quando o autorizam o porte e o carater mais ou menos oficial do empreendimento: guerra de Jerônimo LerTão, guerra de Parnaíba, guerra a que ora vamos com o Sr. João Pereira de Sousa capitão.

Os que participam da emprêsa não tem denominação especial. Soldados dêste arraial é a expressão feliz que 
só uma ou duas vêzes aparece. Em regra, vão tôdos englobados numa palavra genérica: homens, gente ou companhia" (6).

Há também a palavra tropa, não enunciada por ALCÂNTARa MACHaDo por não a ter visto nos Inventários e Testamentos, mas que é coetânea das demais enumeradas, como o prova êste passo de Pedro Taques: "Antes de se ausentar de São Vicente para o reino, o governador MARtim Afonso de Sousa intentou conseguir descobrimento de minas: preparou uma grande tropa e bem fornecida de armas contra o poder da multidão dos índios que habitavam o sertão da costa do sul; porém com a rota que teve perdendo oitenta homens as vidas, ficou sem efeito a pretendida diligência" (7).

Curioso é assinalar que narrando o mesmo sucesso empregou Frei Gaspar da Madre de Deus a palavra bandeira, conforme se pode ver no seguinte trecho: "A sua última ação memorável no Brasil, (refere-se a Martim Afonso de Sousa) teve por objeto o descobrimento de Minas. Constando-lhe por informação dos índios, que nas ' vizinhanças de Cananéa, havia ouro, aprontou uma Bandeira (sic) de 80 homens, e por êles mandou examinar o sítio indicado das Minas, mas com sucesso infeliz; porque os bárbaros Carijós, senhores do país existente ao Sul do Rio de Cananéa, mataram os exploradores das minas, antes de as descobrirem" (8).

Talvez se possa adiantar a afirmação de que a palavra bandeira começou a ser empregada para denominar a entrada, jornada ou tropa, mais ou menos pela época de

(6) Alcântara Machado Vida e Morte do Bandeirante - 2.a edição - Emprêsa da Revista dos Tribunais, 1930, pags. 262/263.

(7) Pedro Taques de Almeida Pais leme - História da Capitania de Sầo Vicente - Editora: Cia. Melhoramentos de S. Paulo s/d, pag. 67.

(8) Frei Gaspar da Madre del Deus - Memórias para a História da Capitania de São Vicente, 3.a edição (Cia Melhoramentos de São Paulo), 1920, pag. 190. 
Frei Gaspar, que viveu de 1715 a 1800 , e cujas Memórias para a História da Capitania de São Vicente são de 1797. Frei Gaspar e Pedro Taques (1714 - 1777), foram contemporâneos, tendo até realizado estudos em comum (9).

Mas a obra dêste foi escrita primeiro, mais ou menos em 1770.

Ora, os Inventários e Testamentos, que foram tão zelosamente examinados por Alcântara MaGhado e não denunciam a presença da palavra bandeira, abrangem o período de 1578 a 1700 . Se nesses documentos a palavra não figura, se Pedro TAques também não a emprega (10),

(9) Cf. Afonso de E. Taunay, no escorço biográfico que antecede a História de Pedro Taques, eđição cit., pag. 32.

(10) Que no tempo de Pedro TaQues ainda não era corrente a designação das entradas por meio da palavra bandeira, e nem muito menos, empregada a sua derivada, bandeirante, pode-se verificar pelas numerosas vêzes que o cronista nomeia os fundadores de vilas espalhadas pela capitania, aos quais chama sempre de paulistas, numa repetição que não se daria, se a palavra bandeirante já fosse de uso comum. Vg. A vila de Curitiba serra acima e Sertão de Paranaguá tem minas de ouro de lavagem, e tão antigas que foram descobertas no ano de 1680 pelo paulista Salvador Jorge Velho".

"A Vila de Santa Anna de Parnaíba foi fundada pelo paulista ANDRÉ Fernandes".

"A Vila de Nossa Senhora da Candelária de Itú foi povoação do paulista Domingos Fernandes com seu genro Cristovão DINís".

"A Vila de Nossa Senhora da Ponte de Sorocaba foi povoação que fundou pelos anos de 1670 o paulista Baxmazar Fernandes".

"O sítio de S. João do Atibaia foi estabelecimento potentado paulista Jerônimo DE CAMARgo"

“A Vila de Nossa Senhora da Conceição do rio Paraíba Jacarai foi ereta em tempo do donatário Diolgo dE FARo E Sousa, pelos anos de 1562, e dela foi povoador e fundador à custa da própria fazenda o paulista Antonto Afonso, com seus filhos Antonio Afonso, Francisco Afonso, Bartolomeu Afonso, Estevão Afonso".

Ainda há outras referências a nomes de bandeirantes semeadores de currais e espalhadores de povoados, mas Pedro TAques sempre os designa por paulistas.

Vide a História da Capitania de Süo Vicente”, edição citada, pags. 142 a 153. 
mas em 1797 ela vai aparecer já grafada pela mão de FreI Gaspar da Madre de Deus, pode-se concluir que o seu uso deve ter começado a ser corrente só no último quartel do século XVIII, e não no decorrer do século XVII, "na centúria das grandes e atrevidas expedições", como afirma Bernardino José de Sousa no seu valiosíssimo Onomástico Geral da Geografia Brasilieira (11).

Ao tempo das expedições só temos notícia de haver sido uma única vêz empregado êsse têrmo, e mesmo assim, não no sentido posterior, mas na acepção que já surpreendemos em Rui de Pina e Ferreira de Vasconcelos. Quem disso nos dá conhecimento é Belmonte, cujo passo vale a pena transcrever por inteiro: "Quanto à bandeira que os paulistas levam... No começo do século, em 1603, não existe em São Paulo nenhuma bandeira da cruz da Ordem de Cristo, dos domínios ultramarinos de Portugal. No dia 4 de Janeiro dêsse ano, o procurador do Conselho requer" que se ajunte o povo para pedirem ao povo dinheiro para uma bandeira, porque não há na vila, nem o Conselho tem dinheiro para isso".

Se a Câmara não possue uma bandeira, nem tem dinheiro para isso, não admira que, pelo menos no início do século, os paulistas levem ao sertão outros pendões que não o das quinas. Os padres Justo Mansilla e Simom MaCETA, na ruidosa Relación de los Agravios afirmam que, quando os. paulistas investiram contra as reduções jesuíticas de Guairá e Iguaçú "las vanderas que levavam no teniam las armas del rey sino outras señales diferentes".

Que sinais ou insignias serão? O padre VAsQues TruJILLo, provincial do Paraguai, em carta que escreveu a Filipe iv, em 12 de Junho de 1632, afirma que os bandei-

(11) 3.a edição, publicada na Bahia, em 1927, da Nomenclatura Geográfica Peculiar ao Brasil, livro que hoje se intitula Dicionário da Terra e da Gente do Brasil, incluida na "Brasiliana" da Cia Editora Nacional, de São Paulo, obra tão valiosa que já se encontra de novo esgotada, o que nos impediu de confererir, nesta última edição, o verbete que nos ocupa. 
rantes não o reconhecem como rei, pois tem soberano próprio, cujas insignias e brasões êle viu nas bandeiras que os invasores levavam. Embora o informe possa ser verdadeiro, não está de acôrdo com a relação da viagem que o governador Valverde faz, em 1657, aos pueblos jesuíticos do Paraná, nem com a carta do padre Miguel Gomes, datada de 1651, os quais viram, entre os troféus tomados aos bandeirantes na refrega, uma bandeira com a efígie de Santo Antônio.

É possível, contudo, que os cinco estejam certos e que, na legião de Raposo Tavares houvesse mais de uma bandeira - justa compensação ao fato de, nas Atas e nos Inventários, não se encontrar senão raríssimas referências ao pendẫo bandeirante.

Assim, parece que, a primeira vêz a empregar-se o têrmo bandeira, no planalto, na sua acepção de sertanista, é no requerimento que os oficiais da Câmara de 1612 enviam ao governador da Capitania, queixando-se da ação draconiana do administrador MATEus DA CoSTA ABORIM: “.. o dito administrador os avexa com excomunhões sendo a jurisdição real de sua magestade e sua justiça não indo contra a ninguem nem levantam bandeira.

Seja, porém, como fôr, o certo é que a denominação de bandeirantes dada, nos primórdios do século XVII, aos ciclópicos desbravadores paulistas, preenche um espaço que a pobreza documental do seiscentismo deixou em claro. E é assim, com a bandeira desfraldada no recesso das florestas pávidas, que os vemos passar, rumo ao desconhecido, para a fortuna ou para a morte.." (12).

Vemos, assim, que a versão referente ao emprego da palabra bandeira, já no século XVII é aceita também por Belmonte, que acompanha nêsse ponto a Bernardino José de Sousa e Taunay, tese essa que não coincide com a de AlcÂNtara Machado, cuja maior exatidão parece ser con-

(12) Belmonte - No tempo dos Bandeirantes - 4. ${ }^{\mathrm{a}}$ edição, s/d, (Cia Melhoramentos de São Paulo), pags. 177 e ss. 
firmada pelos textos de Frei Gaspar e Pedro Taques, por nós acima citados.

Como na elaboração dêste trabalho não pudemos ter em mãos o primeiro tomo da História Geral das Bandeiras Paulistas, do eminente Mestre Afonso DE TAuny, onde deve encontrar-se algo mais do que o referido no verbete do Dicionário de Bernardino José de Souza, não temos base afirmar que ao ilustre Historiador dos Bandeirantes tenha passado despercebido êste pormenor, a êle, que justamente, com tão magno saber, preparou tanto a edição da História de Pedro Taques, como a das Memorias de Frei GasPar. Por isso, fica em pé a interrogação: a palavra bandeira, na acepção de entrada, foi empregada já no século XVII, ou sòmente no correr do século XVIII?

\section{Bandeira, porque?}

Já vimos as principais variantes semânticas ocorridas com a palavra bandeira, que primeiro foi sòmente empregada no sentido de emblema, do pendam da linguagem arcáica; passou depois a ser designativo de certa hierarquia militar, vindo a denominar em seguida o próprio agrupamento a que servira de símbolo. E dessa acepção é que no Brasil veio o têrmo assumir novo significado lexicológico, passando a designar a entrada terrestre dos desbravadores do sertão, para o apresamento de índios e busca de ouro e pedrarias.

Mas - e a pergunta já foi feita inúmeras vêzes — por que se batizou com o nome de bandeiras a essas entradas que eclodiram nos séculos XVII e XVIII, principalmente em Piratininga?

De uma das respostas lembrou-se Alcântara Machado, que assim a resumiu: "com a prudência que lhe é peculiar, o sábio Capistrano recorda, a propósito, a usança 
tupiniquim de alçar uma bandeira à guisa de declaração de guerra" (13).

Essa é uma versão, diríamos, autótone, da usança, que seduz pelo seu cunho de brasileirismo, mas que o próprio CaPistrano de ABReu apresentou sem muita convicção de corresponder a uma origem válida. Fê-lo através de um enunciado dubitativo: "Bandeiras eram partidas de homens empregados em prender e escravizar o gentío indígena. O nome provém talvez do costume tupiniquim, referido por ANCHIETA, de levantar-se uma bandeira em sinal de guerra" (14).

Mas o próprio Alcântara Machado, tão lesto em recordar a sugestão de Capistrano, pelo visto não a aceitou, pois no mesmo momento propõe outra explicação: "Não será impertinência lembrarmos também que, nas empresas de caracter militar mais acentuado e de maior importância, os expedicionários iam classificados em companhias, e cada companhia levava o seu pendão. Dizem-o das forças que assaltaram em 1629 as missões de Guairá e Igaraçú, os autores da Relación de los Agravios, sublinhando que as bandeiras hasteadas pelos paulistas não mostravam as armas de El-Rey, mas outros sinais diferentes" (15).

A de Alcântara Machadó é no fundo a mesma explicação de Capistrano, com a variante de não derivá-la de uma. usança de origem tupiniquim.

Mostrando o cuidado de muitas leituras, Bernardino JoSÉ DE Sousa ao perguntar também qual a razão de ser desta denominação, apresenta o melhor resumo das opiniões existentes, em trecho que vale a pena transcrever por inteiro, dadas as muitas lições que encerra:

(13) Alcântara Machado — Vid̛́a e Morte do Bandeirante, 2.a ed. pag. 260.

(14) J. Capistrano de Abreu, Capítulos de História Colonial, 4.a edição, 1954, Livraria Briguiet, pag. 178.

(15) Ob. cit., pag. 260. 
"Divergem os autores brasileiros. Afranio Peixoto (Minha terra e minha gente), Capistrao de Abreu (citado por Delgado de Carvalho em sua Chorographia), Gentil Moura (As Bandeiras Paulistas) e outros, a maioria, dizem provir do facto de terem as bandeiras uma insignia, um estandarte, uma bandeira, em tôrno dos quaes se reuniam os expedicionários, que os conduziam como simbolos de guerra; Arthur Orlando (Brasil. A Terra e o Homem) e Osorio Dugue Estrada (História do Brasil) derivam-na de bando capitaneado por um caudilho; Rocha Poмвo (História do Brasil, VI vol.), invocando a autoridade de J. MIRANDA (História Militar do Brasil, publicada nos Annaes da Biblioteca Nacional do Rio de Janeiro, vol. 22), indica, a nosso aviso, a verdadeira origem do têrmo. Bandeiras, diz o mestre, "chamavam-se pequenos grupos de assalto que se destacavam de um corpo de tropas ou de uma guarnição, com alguma incumbência arriscada e dependente mais da rapidez do ataque do que de combate leal.

"De feito, além de J. Mrrales, no livro clássico de Latino Coeluo, História Militar de Portugal —, à pag. 6, encontramos o nome de bandeiras ou companhias, como fracçôes de tropa que combatiam dispersas e isoladas, antes do século XVII. Segundo lemos na Encyclopedia Hispano-Americana, dava-se o nome de bandeira, primitivamente, ao tropel de gente armada, e depois, às companhias dos terços de infantaria. Por outro lado, o insigne mestre Theodoro Sampaio, em notas que nos forneceu, afirma não ser a bandeira signal que apareça nos bandos sertanistas, o que concorda com a opinião de Francisco de Paulo RiBEIRo, numa Memória sôbre as Nações Gentias (Rev. do Inst. Hist. e Geog. Brasileiro, Tomo III, pag. 143), na qual lemos: "Eis-aqui pois formada uma bandeira, nome que dêsde muito tempo dão os moradores a êstes ajuntamentos, e dão-lhe tanto sem motivo, quanto porque é insignia esta. 
ou signal, que não aparece ali, como porque primeiro se lhes deveria chamar bandos de homens tumultuosos, do que batalhão concertado. "Julgamos assim, muito mais plausível, que o nome de bandeira, dado às caravanas em marcha pelos sertões, seja uma revivescencia no Brasil das companhias de assalto que outr'ora, na metropole, eram incumbidas de reconhecimentos arriscados e entrepresas temerárias: na prêsa do índio solerte, na procura do ouro, da prata, das esmeraldas e outras pedras preciosas, no combate aos traiçoeiros quilombólas, na penetração e colonização de uma terra ignota e virgem, tudo era uma cilada, uma insídia, um perigo instante, e aquela gente abandeirada, que se confessava e fazia testamento antes de partir, revelara inédita coragem e audácia sem par" (16).

Tais e tantas teorias levaram o economista J. F. NoRMANo a confundir etimologia com significado lexicológico de palavras, conforme se vê no resumo que de tudo isso nos deu êle em livro valioso que sôbre o Brasil escreveu: “A palavra "bandeira" teve duas etimologias diferentes: no primeiro periodo foi adotada como derivada de "bando", isto é, grupos armados, constituídos de horrens que naturalmente se organizavam sob regras militares. Nas organizações posteriores, a palavra "bandeira" passou a designar os grupos formados sob o signo representativo de um ideal, consubstanciado num pavilhão próprio. Os futuros bandeirantes inscreviam-sè nos registros das Câmaras Municipais, organizavam o seu pavilhão e obedeciam à direção de um chefe. As entradas eram de origem local, ao passo que as bandeiras tinham diferentes fontes de formação. Eram organizadas pelo Govêrno Português, pélo govêrno colonial, pelos donatários das capitanias e pela

(16) Bernardeno José de Sousa, Qnomástico Geral da Geografia Brasileira, 3.a edição, Bahia, 1927, verbete, “bandeira”. 
iniciativa particular - sendo que estas últimas caracterizavam sobretudo as bandeiras paulistas" (17).

Salvante a confusão linguística assinalada, existe nêsse resumo um conjunto de noções, muito valiosas para explicar

(17) J. F. Normano - Evolução Econômica do Brdsil (Tração publicada na "Brasiliana" da Cia. Editora Nacional, São Paulo, 1939, pag. 80).

(obs). Pena que um erudito de tão grandes méritos, como foi o nosso JoÃo RIBEIRo, não nos tivesse deixado algumas observações sôbre a palavra bandeira, a exemplo do que fiêz para o têrmo monção, cujo estudo etimológico, breve mas magistral, está em seu livro Curiosidades verbais, edição Melhoramentos, s/d (1927?), pag. 181 e ss., do qual transcrevemos o seguinte trecho, demonstrativo da cultura filológica do grande mestre brasileiro: "A monção que, ao primeiro exame, parece uma expressão latina (motione) é diversamente um têrmo árabe que os portuguêses aprenderam dos pilotos mouriscos orientais.

A palavra arábica é mausim e tem o sentido literal de tempo fixado para qualquer solenidade.

A prosodia primitiva que encontramos ainda em Garcia de Rezende é moução; a primeira syllaba da palavra ficou inteiramente nasalizada por se iniciar com o nasal $\mathrm{m}$ (assim sucedeu a mim por mi, muinto, pronúncia usual de muito, e mancha por macha, mácula).

Dest'arte, monção formou-se de moução mounção.

Os árabes marcam com o vocábulo mausim e mausam o tempo próprio de qualquer cousa. No Líbano, segundo informa Yule ha a monção dos trabalhos da sêda.

Garcia da Orta nos Colloquios da İnäia emprega a palavra monção para designar o tempo das mangas: "A monção dellas he nas terras temporans em abril e nas outras terras serodias em maio e junho" - II, 100.

O erudito annotador Conde dE FicalHo (como já o fizera YULE) assegura que esta phase de OrTa é a única em autor português em que monção se acha com o sentido próprio do mausim, árabe, isto é, o de estação do anno (e mais especialmente os mêses de peregrinar a Méca).

$O$ têrmo generalizou-se naturalmente entre os navegantes $\mathrm{e}$ mesmo entre os que jornadeavam em terra. Sabemos pela história do Brasil que os nossos bandeirantes partiam na monção que vinha ser a época mais propicia às longas investidas pelo sertão. Parece mesmo que o vocábulo passou a designar a própria expediç̃o já reunida e organizada no momento de partir. 
a gênese da bandeira e de sua denominação, a qual não estava alheia a idéia de bando, como veremos no final dêste trabalho, o que foi com muita subtileza observado pelo atilado pesquizador norte-americano que tão bom livro nos legou.

\section{Bandeirante e bandeirismo na derivação gramatical}

Aceita a lição de Carlos Góis, quanto à formação brasileira do têrmo bandeirante, devemos lembrar que essa transformação se operou através do processo chamado de derivação, que consiste no acréscimo, sôbre as palavras existentes, "de certos elementos formativos com que adquirem sentido novo, referido contudo ao significado da palavra primitiva" (18).

Ésse processo de derivação, se faz de dois modos: pelo acréscimo do elemento formativo no início, ou no fim da palavra. Se no início, trata-se de derivação prefixal; se no fim, de derivação sufixal.

$\mathrm{O}$ têrmo bandeir (a) ante, como se vê, foi formado pelo processo de derivação sufixal, com acréscimo do elemento ante, procedente dos sufixos ans, antis, particípios do presente da língua latina, que designam qualidade ou estado, conforme ensina o Prof. Ernesto Carneiro Ribeiro (19).

Portanto, bandeirante qualifica aquele indivíduo que acompanha ou integra uma bandeira, como caminhante qualifica o que caminha, ou negociante, o que negocia. Esse sufixo pertence ao grupo dos que servem para formar adjetivos de substantivos.

Da palavra bandeira, e não de bandeirante, derivou-se, por sua vêz o têrmo bandeirismo, com o natural processo

18) M. SAId Alr, Formação das palavras e Sintaxe do Português Histórico, 2.a parte da Gramática Histórica da Língua Portuguêsa. Cia Melhoramentos de São Paulo, 2.a edição, s/d.

(19) Serões Gramaticais, $4 .^{a}$ edição, pag. 98. 
de supressão da última vogal do elemento básico, e anexação do respectivo sufixo (bandeir (a) ismo), uma vêz que repugnaria à índole da língua a manutenção do inútil ditongo, a infringir a lei da economia vocabular.

Pelo mesmo motivo não teve melhor fortuna a palavra bandeirantismo que, se na linguagem imperasse a lógica, seria a mais própria para designar o fenômeno social dos bandeirantes.

Ensina o Prof. SAID Al, que algumas poucas palavras existiam no latim da idade média terminadas em ismo, entre as quais catolicismo, catecismo, paganismo ou exorcismo, que facilmente se vulgarizaram sem que por isso a linguagem popular manifestasse a disposição de converter tais palavras em tipo produtor de novos derivados en ismo.

Coube à língua culta, e não à popular, aproveitar-se de palavras internacionais e incorporá-las ao vocabulário vernáculo, acrescidas da terminação ismo, que a partir daqueles poucos têrmos qualificadores de doutrinas, a isso se prestavam. Assim se formou um grande número de nomes de doutrinas religiosas, filosóficas, políticas ou artísticas, como, calvinismo, protestantismo, ateismo, positivismo, materialismo, socialismo, gongorismo, simbolismo etc.

A êsses primeiros grupos designativos terminados em ismo acrescenta o Prof. SAID Ali mais dois outros, um dos quais com grande número de vozes. Êsse é o grupo de linguagem, em que o paciente filólogo distinguiu:

a) peculiaridade do falar de certas pessôas (plebeismo, vulgarismo).

b) imitação de língua estrangeira (latinismo, helenismo, galicismo) .

c) diferenciação de certas expressões com as do falar usual (arcaismo, neologismo, solecismo, barbarismo). 
d) linguagem científica para exprimir fenômenos (magnetismo, galvanismo, traumatismo etc).

Por fim, distinguiu o preclaro gramático, também uns grupo de palavras que exprimem "a maneira de agir ou de pensar de acôrdo com o procedimento ou a doutrina própria de certo gênero de indivíduos", como, heroismo, pedantismo, fariseismo, patriotismo, servilismo etc.

Pela classificação do Prof. SAId Aur parece-nos caber nêste último grupo a inclusão da palavra bandeirismo, por ser designativa da maneira de proceder, de agir, dos componentes das bandeiras.

Não há uma doutrina do heroismo, mas SAId Ali exemplificou também com esta palavra a sua regra. O Bandeirismo também não é uma doutrina, mas um modo de proceder, devendo ser, portanto, incluído no último grupo das palavras terminadas em ismo, segundo a classificação do eminente gramático brasileiro.

\section{Outras derivações menos empregadas}

Não precisamos estar mencionando outras derivações da palavra bandeira, depois que, com a palavra bandeirante, se rompeu a comporta de vozes novas, da primeira originadas. Vimos como se formou a trindade vocabular básica: bandeira - bandeirante - bandeirismo.

Não há muito, o Mestre destes assuntos, o eminente Prof. Afonso de Taunay imprimia de seu próprio cunho o têrmo bandeirógrafo, que logo deu bandeirografia, nome justo para expressar as atividades daqueles que, seguindolhe o maravilhoso exemplo, criaram tôda uma literatura de pesquiza e esclarecimento dêsse extraordinário periodo da nossa história.

Um neologismo não bastou, porém, para o entusiasmo dos bandeirófilos. Erigindo o assunto bandeira em maté- 
ria de disciplina autónoma, veio a seguir a expressão bandeirologia, de que já existe, há anos, um curso impresso: "Curso de Bandeirologia".

o Dicionário de Morais, em sua segunda edição, só conhecia e acolhia a palavra bandeira no seu sentido restrito, como já vimos.

O léxico de Candido de Figueiredo, na sua $8 .^{a}$ edição, já enumera dez vocábulos derivados de bandeira.

Recentemente veio a lume uma edição feita por filólogos portuguêses do dicionário de Morais e Silva, agora em seis grandes volumes, e ali se encontram nada menos do que dezesseis palavras derivadas e dezenove expressões compostas de bandeira.

Quanto ao têrmo originário, o mesmo léxico imprime uma certa ordem às várias acepções que a palavra comporta, indicando as do seguinte modo:

$\begin{array}{lll}\text { Bandeira } & 1 & \text { (de banda) } \\ \text { Bandeira } & 2 & \text { (com o significado de palerma) } \\ \text { Bandeira } & 3 & \text { (têrmo de zoologia) } \\ \text { Bandeira } & 4 & \text { (brasileirismo designativo de sina- } \\ & & \text { leiro das vias férreas). }\end{array}$

\section{Retorno ao problema etimológico}

Feita essa breve resenha histórica, literária e gramatical da palavra bandeira, voltemos ao problema etimológico, indicando as lições dos filólogos por nós consultados.

Retornando a Carlos Górs, vemos que o dicionarista. mineiro assinala a existência de dois radicais band, o primeiro de origem permânica, com o valor de ligar, reunir, que a seu ver orgiinou band (0), (originariamente rebanho), band (eira), band (a) e band-ol - (a) eiro, (através do espanhol bandola).

O segundo radical band, indicado por CarLos Góis, é por êle tido como derivado do radical bann, que significa. 
edito, citação, e que vem, a seu ver, do baixo latim, o que exemplifica êle com as palavras band-um, band (i) um, presentes na formação, entre outras que indica, da palavra band (o), (edital), donde contra-bando, contra o edital, isto é, contra a lei; band-ido, do it. originariamente homem fora do bando, isto é, fora da lei, etc.

\section{O que registra o Dicionário Etimológico de Antenor Nascentes}

Oferece o ilustre filólogo, em poucas linhas, no agora primeiro volume do seu Dicionário, pois que o segundo, dedicado à Onomástica, já veio a lume, o resumo das complicações em que se debatem os rastreadores da palavra bandeira. Diz êle: "Bandeira - do latim *bandaria. (A. Coelho, Nunes, Gram. Hist. 167, 180) calcado no radical germânico que deu banda. M. LubK, REW, 929, tira o port., o esp. e o it. do fr. bannière, que deriva do fr. *banna, sinal. Stappers apela para o got. bandva ou bandvo. A Academia-Espanhola deriva bandera de banda. PETROCCHI liga bandiera a banda".

Convém pôr em destaque ás várias teorias etimológicas da palavra bandeira, seguindo o enunciado no verbete do dicionário de $\mathrm{A}$. Nascentes, que não propõe pessoalmente nenhuma solução, mas assinala as opiniões existentes.

$1^{0}$ - A do radical germânico band, que deu a palavra portuguêsa banda - passando pelo latim *bandaria. Aceitam essa etimologia: Adolfo Coelho, José Joaquim Nunes e, como vimos, Carlos Góis, que não se referiu à palavra intermediária uma vêz que não estava fazendo um dicionário etimológico, mas de raizes e cognatos. Também Candido Figueiredo aceita essa etimologia, mas no seu Dicionário apresenta uma pequena variante na grafia do vocábulo intermediário, que êle escreve *banderia, em lu- 
gar de "bandaria. - Caldas Aulete (20) indica a etimogia de bandeira do seguinte modo: "F. Lat. *bandaria, sôbre o radical de banda". E preciosamente assinala a pronúncia da palavra em Portugal: "Bandeira - (dai) s.f.", o que mostra ter ocorrido com a palavra o conhecidíssimo fenômeno de transposição de letras, a partir da forma intermediária suposta, (bandaria $=$ bandaira) vestígio que ficou conservado na pronúncia portuguêsa, mas que se perdeu na brasileira, daí surgindo talvez a razão porque Candido de Figueiredo acreditou que a forma suposta tivesse sido *banderia, e não *bandaria, o que melhor justificaria a atual ortografia, ( ${ }^{\star}$ banderia = bandeira), dentro do mesmo fenômeno de transposição de letras.

$2^{\circ}$ - A do radical francês, *banna, que significa sinal, palavra também de suposta existência, como bandaria, e da qual se teria derivado o têrmo bannière, do qual o português, o espanhol e o italiano foram tirar os seus têrmos correspectivos, que são: bandeira, bandera e bandiera. Essa é a etimologia indicada pelo filólogo MEYen LubKe no seu clássico ${ }^{*}$ Romanisches-Etymolisches Wortenbuch, citado abreviadamente-REW, cuja $3^{\text {a }}$ edição, inteiramente refundida, foi publicada em Heidelberg, em 1935.

$3^{\circ}$ - A da origem na palavra gótica bandva, ou bandvo, proposta por Stappers e, finalmente, a teoria da origem da palavra bandeira no têrmo banda, que é a indicada pelo Dicionário da Real Academia Espanhola para o esp. bandera, e por Petrocchi para o it. bandiera.

Qual destas teorias é a verdadeira?

(20) A edição consultada é a $3 .^{a}$, de 1948, da Parceria Antonio Maria Pereira, Lisboa. 


\section{A resposta de Augusto Magne}

Ao Instituto Nacional do Livro compete organizar e publicar um Dicionário da Língua Nacional, finalidade que vai sendo atingida através de contribuições parciais, cuja primeira plana é ocupada pela notável obra do sapientíssimo Padre Augusto Magne, Dicionário da Lingua Portuguesa", abrangendo especialmente os períodos medieval e clássico, e do qual já estão publicados dois volumes, correspondentes às letras $\mathrm{A}-\mathrm{AF}$ e $\mathrm{AG}-\mathrm{AL}$.

Não está, portanto, publicado ainda o verbete bandeira, mas no verbo abandar apresenta o erudito filólogo a mais completa exposição de quantas até agora pudemos conhecer, relativamente aos radicais do substantivo bando, no sentido de grupo, sôbre o qual o Pe. Magne enumera a existência de diferentes vocábulos, parecidos na forma, diz o autor, mas que nos deram derivações faceis de se confundirem, dada a comum origem germânica de tôdos êles.

Êsses radicais são os seguintes:

a) o subst. alem. Band, fonte do nosso subst. fem. venda, significando a faixa com que se cobrem os olhos, e do qual se derivam os verbos vendar e desvendar. Desse radical se originaram várias palavras francesas, entre as quais bande ${ }^{1}$ (ligadura), do qual procede o port. banda ${ }^{1}$ com o significado de faixa, fita, donde sai o verbo bandar, isto é, guarnecer de fitas. Da mesma origem, diz MAGNE, dimanam o francês bande ${ }^{2}$ e o português bando ${ }^{1}$ representando gente reunida ou tropa, donde o verbo debandar e o subst. fem. debandada. A forma feminina band $^{2}$ ensina Augusto Magne que é mera variante de bando $^{1}$, e significa reunião, grupo, companhia. Há uma terceira acepção de banda, com o significado de lado, parte lateral, que não vem ao nosso propósito.

b) O subst. germânico ban, que significa desterro, proscrição, sendo que dessa raiz germânica procedem o fr. 
ban (ban de mariage) e o port. banhos (banhos de casamento).

A forma bann (subst. masc. alem.) com o significado de notificação pública, ordem ou proibição, deu o verbo italiano bandire (apregoar), do qual afirma Augusto MaGNE ter saido o nosso verbo banir (desterrar por sentença ou pregão). A mesma forma originou o subst. masc. ban$d o^{2}$, com o significado de proclamação, anúncio público.

c) Diferentemente, porém, do que assevera CarLos Góis, que do radical band (germânico) pretende que se derive band (eira), ou os etimologistas citados por NASCENTES que afirmam sua derivação de banda, (que, segundo vimos, também procede de band, não havendo, pois, motivo para se aceitar uma derivação secundária quando existe o radical comum às duas palavras), o Dicionário de Augusto Magne indica o gótico bandwa, bandwo, significando sinal, como radical de bandeira, através da fórma latinizada bandum, não porém diretamente, e sim, através da fórma alatinada bandaria, da qual afirma proceder também o francês bannière.

A versão de Magne coincide com a de Stappers, como vimos no Dicionário de NAscentes, no sentido de aceitar o gótico bandwo (bandvo?) e bandwa (bandva?) como radical da palavra. A abonação de Augusto Magne, que não faz referência a Stappers, é a seguinte:

"Kluge-Gotz p. 37, 38 etc. rew 927, 929, 930, 933 a”.

\section{$\mathrm{XI}$ - Conclusão}

Esta aproximação das diferentes teorias apresentadas pelos etimólogos mostra como é árdua e por vêzes intrincada essa pesquiza, da qual saímos insatisfeito e incerto de termos obtido um resultado concreto e definitivo.

De qualquer maneira, parece que se pode afirmar que a origem vocabular de bandeira ainda permanecerá 
envolta em névoas de incerteza, sendo mesmo improvável que algum dia se aclare completamente o problema.

Um resultado que nos parece evidenciado ao término desta rebusca, é o de que há um dualismo etimológico decorrente da existência de radicais de origens linguísticas diferentes e que emprestam ao vocábulo tanto a idéia de grupo como a de símbolo. Esse dualismo etimológico persiste, é como que reproduzido no sentido histórico da bandeira sertanista, que também consubstancia uma dualidade de objetivos, como bem foi observado por Olrveira Via$\mathrm{NA}$, em passo que vale a pena recordar:

"Há dois tipos principais de bandeiras. Há as bandeiras de guerra e há as bandeiras de colonização. Êste segundo tipo domina na expansão paulista para o sul, na colonização dos campos paranaenses, catharinenses e riograndenses e no povoamento da orilha meridional até Laguna. Os bandos sertanistas de simples exploração do sertão, de prêa ao índio, de caça ao ouro, de combate aos quilombos pertencem ao primeiro tipo.

Esta diferença de tipos influi na composição da bandeira. Na bandeira colonizadora, é o próprio domínio, com tôdos os seus elementos, que se desloca. Na bandeira de guerra, só figuram os elementos combatentes do latifundio. Quando, descobertas as minas, entra-se propriamente na fase da exploração industrial, as bandeiras de guerra se transformam em bandeiras de colonização: e a sua composição se complica adquirindo o feitio das de segundo tipo; e o escravo negro é preferido ao mameluco e ao índio. O núcleo social, daí resultante, sofre, na sua estrutura ethnica, a consequência dessa transmutação de tipo: o negro e o mulato predominam (21).

Isto confirma o destaque em que se coloca o pesquizador J. F. Normano, que, conforme vimos, teve um vislumbre de extraordinária exatidão quando viu no feno-

(21) Oliveira Viana, Populaçóes Meridionais do Brasil, 4.a edição, 1938, pág. 98 . 
meno da bandeira um dualismo de origem vocabular acentuado pelo seu conteúdo historico. Realmente, embora proceda a palavra bandeira de um radical gótico diverso do radical germânico que deu origem à palavra bando, o conjunto sertanista teve sua denominação derivada das duas idéias. Foi o que ficou delineado no correr dêste modesto trabalho, lavrado grosseiramente por quem nada sabe de história nem muito menos de filologia, mas que por bem pago se dará, se alguem, armado dos conhecimentos que lhe faltam, retomar o assunto para esclarecê-lo e salientar que esta tentativa foi apenas um ato de audácia, pois que a ignorância é sempre audaciosa. E como justificativa da empresa vá o latim que sempre é prestativo: Ignorantia in alieni facti tolerabilis error est". 